\title{
Should we welcome food industry funding of public health research?
}

\author{
Researchers should accept research grants from the food industry, write Paul Aveyard and Derek \\ Yach, but Anna B Gilmore and Simon Capewell say that it biases science
}

\author{
Paul Aveyard professor of behavioural medicine ${ }^{1}$, Derek Yach executive director ${ }^{2}$, Anna B Gilmore \\ professor of public health ${ }^{3}$, Simon Capewell professor of public health and policy ${ }^{4}$
}

${ }^{1}$ Nuffield Department of Primary Care Health Sciences, University of Oxford, Oxford OX2 6GG; ${ }^{2}$ Vitality Institute, New York, USA; ${ }^{3}$ UK Centre for Tobacco and Alcohol Studies, University of Bath, Bath, UK; ${ }^{4}$ Department of Public Health and Policy, University of Liverpool, UK

\section{Yes-Paul Aveyard, Derek Yach}

The food industry consists of farmers, manufacturers, wholesalers, retailers, distributors, and the catering industry. If it disappeared tomorrow, most people in the developed world would die within months. It is a major employer; more people are employed in the food industry in the UK, for example, than any other manufacturing sector. ${ }^{1}$ For these reasons, government policies seek to support the industry. From this perspective, it would be absurd for health policy researchers to shun collaborating with the food industry.

Of course, our aims are not always allied. Many elements of the industry promote and sell food that undermines health. When faced with effective public health actions to curtail consumption of unhealthy products it sometimes fights against the cause of public health. Therefore not all cooperation is appropriate. For example, although industry's views are critical to developing public policy, its presence when such policy is decided is inappropriate.

But working with the food industry inevitably involves accepting its funding, in kind at least. Take the FLICC study, ${ }^{2}$ in which a supermarket searched its database to find regular consumers of processed food, often high in saturated fat and salt, and asked them to participate in the trial. The trial is testing an intervention to promote the motivation and capacity of shoppers to make better use of front-of-pack "traffic light" nutrient labels and uses loyalty card data to determine the nutritional profile of purchases. The retailer paid the costs of its staff's time used for discussion with researchers and to collect and process loyalty card data. Would the study be better if the researchers had paid the supermarket for their time and information? We doubt anyone would seriously argue so, bearing in mind this would remove funding from other worthy research.

\section{Reputational advantage}

Why might the supermarket co-fund this study? It is because supermarket managers share the goals and values of the researchers. There is no reason they should prefer to sell less healthy food over healthier food. It may offer reputational advantage to help shoppers to make healthier choices. Only the most cynical would argue that collaborating in this way is pretending to do the right thing and merely deflects radical and unpalatable options, such as regulation.

In some cases, the interests of the food industry align so strongly with those of health researchers that industry is willing to pay the entire costs of the study. Basic research on better ways to reduce salt, sugar, and fat; intervention research on the benefits of micronutrients to health; or research on the effect of discounting healthy food on dietary patterns are examples. Leading manufacturers are investing billions of dollars to improve the nutritional quality of their products—well in excess of public research investment.

\section{Strong safeguards}

Independent researchers should be responsible for design, conduct, and analysis of the research and not the company. This implies research organisations accept direct payments from the food industry. Such payments require strong safeguards to avoid bias and the appearance of bias: researchers should have no commercial interest in the product; payments should be made to the organisation not the researchers and should reflect the cost of the research to avoid researchers feeling beholden to the company; the analysis should be done by statisticians independent of the investigators who designed and conducted the study; and researchers should publish the results regardless of the outcome. There are excellent examples of best practice in industry funded food research ${ }^{34}$ and other contested academic 
areas. ${ }^{5-7}$ The alternatives are that the research is not done, that it is done by the company itself, or that the public pays.

In many cases food industry and health goals clearly align and co-funding in kind or through direct payment from industry is appropriate. Examples of bad practice do not invalidate findings from appropriate collaborations. Providing safeguards are in place, no reasonable person should doubt the integrity of collaborative research.

\section{No-Anna B Gilmore, Simon Capewell}

Corporations are legally required to maximise shareholder profits and therefore have to oppose public health policies that could threaten profits. Unequivocal, longstanding evidence shows that, to achieve this, diverse industries with products that can damage health have worked systematically to subvert the scientific process. The research they fund produces uniquely favourable outcomes. ${ }^{8-11}$ Internal documents show how they manipulate evidence in their favour, strategically communicate that evidence to influence public and political opinion, and ultimately minimise regulation and legal liability. ${ }^{8-13}$

The food industry is diverse, but there is a clear conflict between public health and companies that produce ultraprocessed food and sugary soft drinks. It is unsurprising, therefore, that similar evidence is now emerging for these companies. Studies they fund are generally biased in their favour. ${ }^{14}{ }^{15}$ Previously secret documentation shows they are working to ensure research and researchers they fund deflect attention from their products and unwanted regulatory interventions. ${ }^{16}{ }^{17}$ They promote weak or ineffective interventions aimed at individuals rather than upstream population level regulation, and emphasise physical activity and energy balance to the exclusion of diet based drivers of obesity, messaging reinforced by non-governmental organisations fronted by industry funded scientists. ${ }^{16}$

\section{Four flawed excuses}

Much like the case with tobacco, scientists taking money from ultraprocessed food companies typically offer four flawed excuses.

\section{"I am an objective, impartial scientist and cannot be biased"}

Wrong. Industry funded research is significantly more likely to produce outcomes favourable to that industry (rates vary from about five ${ }^{14}$ to $88^{8}$ times). Sometimes researchers are willing to fabricate data or allow corporate lawyers to hide unfavourable studies. ${ }^{8}$ But even well meaning scientists are (often subconsciously) biased, even by small gifts. ${ }^{18} 19$

\section{"I control the data and have freedom to publish, so my research cannot possibly advantage industry"}

Wrong. Extensive evidence shows that quality, peer reviewed studies where scientists control the data and are free to publish are vital to corporate strategies. ${ }^{8}{ }^{13}$ Industry funds these studies, often by the top researchers in the top institutions, because it knows they are safe (that is, the results will not threaten industry interests), will divert attention to alternative risk factors, enhance industry reputation, and create a cadre of indebted experts. ${ }^{8-20}$ These scientists may be doing quality work but it does not advance science. Instead it puts industry in control of the research agenda. By determining what questions are asked and , crucially, not asked, industry can distort the evidence base to defend itself from attack. ${ }^{13}$

\section{"Industry funds are crucial for research"}

Wrong. Industry funding accounts for a surprisingly small proportion of total research funding, less than one tenth in the UK or US. ${ }^{21}$

\section{"Disclosure and peer review provide sufficient redress"}

These are essential and do help, but are insufficient. ${ }^{20}$ Experimental studies show disclosure can, paradoxically, exacerbate rather than reduce the biasing effect of conflicts of interest. ${ }^{22}$ Moreover, conflicts of interest may not be identified as relevant, particularly when industry is deliberately funding distracting research, and even the best peer review can fall short.

\section{What can be done?}

We must not allow the food industry and its allies to use these smokescreens (such as limited industry collaboration in independently funded studies) to obfuscate and delay action on the key issue in this debate- the funding of obesity related research by corporations whose interests are threatened by effective anti-obesity interventions. Until funding models change, our ability to counter the obesity epidemic will be seriously constrained. We therefore need more radical funding models that allow corporations to fund research while protecting that research from their influence.

Previous work shows that dedicated manufacturer taxes, licence fees, or legally mandated contributions (with the funds raised then administered independently from industry) are most likely to maximise transparency and minimise conflicts of interest. ${ }^{23}$ Funding of research through a tax on tobacco and alcohol in California and Thailand shows that this approach is feasible.

Change will not occur until public health researchers refuse to take money from the ultraprocessed food industry. It worked for tobacco; in the early 1990s all bar one UK medical school took tobacco industry funding. That is unthinkable today, and the change has underpinned progress in tobacco control.

Competing interests: All authors have read and understood BMJ policy on declaration of interests and declare the following interests: DY has been employed full time by PepsiCo and Discovery and has had paid advisory roles with PepsiCo, Tesco, and Mars on promoting healthy and sustainable diets; he has also had advisory roles with the Institute of Medicine, Wellcome Trust, and World Economic Forum. PA currently holds research grants paid to his university from the MRC, NIHR, NICE, and Cambridge Weight Plan. All these grants have been or are held under the safeguards outlined in the article. He has worked as an unpaid member of guidelines groups for NICE and is a committee member of the Association for Study of Obesity and the UK Society for Behavioural Medicine. ABG currently hold grants from NIHR, Cancer Research UK, and the New Venture Fund and is a member (unpaid) of the UK Health Forum and the Council of Action on Smoking and Health. SC is a trustee (unpaid) of the UK Health Forum, Heart of Mersey, and UK Faculty of Public Health and is a member of ASH Scotland.

Provenance and peer review: Commissioned; externally peer reviewed.

1 Department for Business Innovation and Skills. Manufacturing in the UK: an economic analysis of the sector. 2010. https://www.gov.uk/government/uploads/system/uploads/ attachment_data/file/31785/10-1333-manufacturing-in-the-UK-an-economic-analysis-ofthe-sector.pdf.

2 Scarborough P, Hodgkins C, Raats MM, et al. Protocol for a pilot randomised controlled trial of an intervention to increase the use of traffic light food labelling in UK shoppers (the FLICC trial). BMC Pilot and Feasibility Studies 2015;1:21.

3 Haddock CK, Poston WS, Lagrotte C, et al. Findings from an online behavioural weight management programme provided with or without a fortified diet beverage. Br J Nutr 2014;111:372-9. doi:10.1017/S0007114513002377 pmid:23920353.

4 Roberts LMMD, McCahon D, Holder R, Wilson S, Hobbs FD. A randomised controlled trial of a probiotic 'functional food' in the management of irritable bowel syndrome. BMC Gastroenterol 2013;13:45. doi:10.1186/1471-230X-13-45 pmid:23496803. 
5 Landray MJ, Haynes R, Hopewell JC, et al. HPS2-THRIVE Collaborative Group. Effects of extended-release niacin with laropiprant in high-risk patients. N Engl J Med 2014;371:203-12. doi:10.1056/NEJMoa1300955 pmid:25014686.

6 Chen ZM, Jiang LX, Chen YP, et al. COMMIT (ClOpidogrel and Metoprolol in Myocardial Infarction Trial) collaborative group. Addition of clopidogrel to aspirin in 45,852 patients with acute myocardial infarction: randomised placebo-controlled trial. Lancet 2005;366:1607-21. doi:10.1016/S0140-6736(05)67660-X pmid:16271642.

7 Imperial Innovations. Apollo therapeutics fund. 2016. http://www.imperialinnovations.co. uk/technology-transfer/apollo-therapeutics-fund/

8 Bero LA. Tobacco industry manipulation of research. In: Late lessons from early warnings: science, precaution, innovation. EEA report No 1/2013.European Environmental Agency, 2013.

9 White J, Bero LA. Corporate manipulation of research: strategies are similar across five industries. Stanford Law Pol Rev 2010;21. https://journals.law.stanford.edu/stanford-lawpolicy-review/print/volume-21/issue-1-academic-integrity/corporate-manipulation-researchstrategies-are-similar.

10 Union of Concerned Scientists. Heads they win, tails we lose. How corporations corrupt science at the Public's expense. Union of Concerned Scientists, 2012.

11 Egilman DS, Bohme SR. Over a barrel: corporate corruption of science and its effects on workers and the environment. Int J Occup Environ Health 2005;11:331-7. pmid:16350466.

12 Michaels D. Doubt is their product. How industry's assault on science threatens your health. Oxford University Press, 2008.

13 Oreskes N, Conway E. Merchants of doubt. Bloomsbury Press, 2010

14 Bes-Rastrollo M, Schulze MB, Ruiz-Canela M, Martinez-Gonzalez MA. Financial conflicts of interest and reporting bias regarding the association between sugar-sweetened beverages and weight gain: a systematic review of systematic reviews. PLoS Med 2013:10:e1001578, e1001578. doi:10.1371/journal.pmed.1001578 pmid:24391479.

15 Nestle M. Corporate funding of food and nutrition research. Science or marketing? JAMA Intern Med 2016;176:13-4. doi:10.1001/jamainternmed.2015.6667 pmid:26595855.
16 O'Connor A. Coca-Cola funds scientists who shift blame for obesity away from bad diets. New York Times 2015 Aug 9. http://well.blogs nytimes com/2015/08/09/coca-cola-fundsscientists-who-shift-blame-for-obesity-away-from-bad-diets/?_r=1\#

17 Kearns CE, Glantz SA, Schmidt LA. Sugar industry influence on the scientific agenda of the National Institute of Dental Research's 1971 national caries program: a historical analysis of internal documents. PLoS Med 2015;12:e1001798. doi:10.1371/journal.pmed. 1001798. pmid:25756179.

18 Cain DM, Detsky AS. Everyone's a little bit biased (even physicians). JAMA 2008;299:2893-5. doi:10.1001/jama.299.24.2893 pmid:18577735.

19 Katz D, Caplan AL, Merz JF. All gifts large and small: toward an understanding of the ethics of pharmaceutical industry gift-giving. Am J Bioeth 2003;3:39-46. doi:10.1162/ 15265160360706552 pmid: 14594489

20 Cohen JE. Universities and tobacco money. BMJ 2001;323:1-2.doi:10.1136/bmj.323.7303. 1 pmid:11440920.

21 Matthews $D$. Is industry funding undermining trust in science? How valid are fears that financial conflicts of interest are damaging confidence in academic research? TimesHigher Educ 2015 Oct 29. https://www.timeshighereducation.com/features/is-industry-fundingundermining-trust-in-science

22 Loewenstein G, Sah S, Cain DM. The unintended consequences of conflict of interest disclosure. JAMA 2012;307:669-70.pmid:22337676.

23 Cohen JE, Zeller M, Eissenberg T, et al. Criteria for evaluating tobacco control research funding programs and their application to models that include financial support from the tobacco industry. Tob Control 2009;18:228-34. doi:10.1136/tc.2008.027623 pmid: 19240229.

Published by the BMJ Publishing Group Limited. For permission to use (where not already granted under a licence) please go to http://group.bmj.com/group/rights-licensing/ permissions 